\title{
How social shopping retain customers? Capturing the essence of website quality and relationship quality
}

\begin{abstract}
Social shopping as a result of the advancement of social media applications is increasing considerably in e-commerce. As a consequence of the multi-faceted phenomenon of social shopping, website managers encounter a lot of challenges in providing their quality website experience to satisfy their customers' needs and in developing relationships among participants, and community. In short, providing excellent quality website experience is crucial to support online customers. Therefore, it is necessary to offer further theoretical conceptualizations as well as detailed empirical evidence for such phenomena in which social shopping are supported and enabled. Thus, this paper attempts to investigate the factors affecting purchase intention of social shopping including two constructs: website quality (i.e., system, information, and service quality) and relationship quality (i.e., satisfaction, commitment, and trust). Additionally we aim to identify the mediating roles of commitment and trust. The empirical results show that the perceived system and service quality are important antecedents of customer satisfaction, but not for the effect of perceived information quality on customer satisfaction. Furthermore, it shows that customer satisfaction significantly influences commitment, trust, and purchase intention, and trust in turn significantly affect commitment. Our empirical results confirm that commitment and trust partially mediate the relationship between satisfaction and purchase intention in social shopping context.
\end{abstract}

Keywords: Social shopping; Social media; Website quality; Relationship quality; Purchase intention 


\section{Introduction}

Social shopping has been regarded as a new model of e-commerce as it provides a new way of accessing customers for merchants (Lee \& Lee, 2012). Social shopping combines product/service sales with consumer participation in a social network context with a synergistic relationship between merchants, consumers, and social network (Lee \& Lee, 2012). Combining social networking with shopping satisfies the need for searching information before shopping and sharing personal experiences online after use (Hajli, 2015). More precisely, social shopping draws customers and merchants together, and facilitates transactions by offering a figure of group discount where customers' social interactions are highlighted during the transaction processes. Put differently, social shopping attempts to employ web technologies to copy the volume discount and social interactions found in physical stores and malls. The rapid development of social shopping is somewhat driven by Web 2.0, which changed the business environment from a business to a user orientated (Lee \& Lee, 2012).

Kaboodle, ThisNext, Wanelo, Crowdstorm, Stylehive, Rakuten Ichiba Taiwan, LuxJoy, WooGii and Pinkoi are some of the examples of social shopping sites, tender virtual communities or blogs for consumers to share shopping thoughts, exchange opinions on specific merchants and recommend their favorites (Hsiao, Lin, Wang, Lu, $\& \mathrm{Yu}, 2010)$. These thoughts, opinions or recommendations are helpful for consumers getting product information of interest and supporting them in making shopping decisions. Namely, before, during and after transactions, relationship quality can construct or obliterate the relationship between business and shopper. Hence, it is important to develop a measure of relationship quality in a social shopping context so that both researchers and practitioners might better understand, and thus hold relationships more efficiently. Rafiq, Fulford, and Lu (2013) proposed that relationship 
quality can be commonly focused on trust, commitment and satisfaction. Hajli (2014, p. 17) argued that "social media benefits commercial transactions of vendors by developing closer relationships with customers, enriching the quality of the relationship, increasing sales and encouraging loyalty to the business". Relationship quality is a crucial factor in relationship marketing literature, and it has impact on loyalty towards a business (Rauyruen \& Miller, 2007). Thus, it is crucial to develop ways of evaluating their quality before ultimately assessing their influence on other significant variables such as transaction performance since numerous academic and managerial resources are focused on better understanding the relationships.

Besides, eMarketer (2008) pointed out that people are more likely to trust the information given by other shoppers like themselves more than that given by companies. Consequently, websites may enhance their sales volume via consumers' trust through the opinions or recommendations shared by other known or unknown shoppers. Albeit perceived trust of e-shopping is critical to support online consumers, it is crucial to offer empirical evidence for such phenomena in which social shopping are supported and enabled. Furthermore, to improve an individual's desire to continue a relationship with an e-retailer, commitment is an important factor for a long term relationship (Garbarino \& Johnson, 1999). Commitment displays the significance of the relationship with service provider that maximizes the efforts to guarantee the relationship (Hajli, 2014). In addition, satisfaction is the crucial determinant of customer loyalty (Hsu, Wu, Chen, \& Chang, 2012). De Wulf, Odekerken-Schroder, and Lacobucci (2001) mentioned that satisfaction refers to the affective state of people from their complete evaluation of the relationship they have with other people. Satisfaction is able to generate a direct and great impact on intention to buy and customer retention by investing in a relationship with consumers (Hajli, 2014). The strength of this 
relationship is a crucial concept in relationship marketing (Rauyruen \& Miller, 2007), and additionally this relationship relies on the e-retailer website quality and how it builds the connection with consumers.

These discussions suggest that in social shopping context relationship quality and website quality are important factors driving repurchase intention of customers. However, there is limited literature focusing on understanding the social shopping behavior and its associated factors. Thus, our study attempts to fill this research gap by examining the interrelationships between website quality (i.e., information, system, and service quality), relationship quality (i.e., satisfaction, commitment, and trust), and purchase intention in social shopping. The study also aims to identify the mediating effects of commitment and trust on purchase intention. The next section explores these factors in detail and proposes theoretical conceptualization and a set of hypotheses.

\section{Literature review and hypothesis development}

The current literature review gives an opulent foundation with which to construct a research model and explores the relationships between website quality (i.e., information, system, and service quality), relationship quality (i.e., satisfaction, commitment, and trust), and purchase intention. Fig. 1 illustrates the research model which is used in this paper. The specific components of our model and related hypotheses are discussed further in detail below.

\section{[Insert Figure 1 here]}

\section{Social shopping}

Social shopping is a type of advertising or promotion through which intermediaries permit local merchants to employ Internet technologies and localize online advertisements in ways that were unavailable to merchants in the past (Lee \& Lee, 
2012). The market potential of social shopping is increased by social networking sites such as Facebook, Twitter, Plurk, and MySpace that help merchants to quickly get a large pool of potential customers and various product or merchant reputation sites such as Yelp and TripAdvisor (Lee \& Lee, 2012). Social shopping sites such as Kaboodle, ThisNext, Crowdstorm, Stylehive, Rakuten Ichiba Taiwan, LuxJoy, WooGii and Pinkoi, provide blogs or virtual communities for consumers to share shopping thoughts, exchange opinions on specific merchandises and recommend their favorites (Hsiao et al., 2010). Therefore, influencing potential consumers through information sharing and interactions of the provided blogs or virtual communities is a significant benefit of social shopping sites. Website managers are developing social shopping functions or launching social shopping networks on their websites due to the increase of social shopping and online shops/auction. Rubel (2005) indicated that social shopping networks is a platform where people can help each other online, get advice from trusted persons, find goods and services, and then purchase them. Other individual's advices or recommendations regarding products/services play a crucial role in social shopping. This is also echoed in the study of Olbrich and Holsing (2011) who suggest that social shopping communities evolve from a linkage of social networking and online shopping. Specifically, consumers generally use the generated electronic word-of-mouth (eWOM) in different online platforms (e.g., online forum, blog, emails, and virtual community, etc.) to decide whether they would trust the firm in an electronic transaction (See-To \& Ho, 2014). As proposed by Gordon (2007), consumers trust the product recommendations on the social shopping networks of websites, as a result their intention to purchase the socially-recommended product is aroused, and thus they may purchase from that website. Therefore, trust is regarded as one of the most important prerequisites for e-commerce success, especially in the social shopping context. 
Furthermore, in a social shopping context, the firms often cooperate with social networking sites such as Facebook and Twitter to encourage their transactions (Stephen \& Toubia, 2010), and in contrast, consumers are able to help sellers' products and services spontaneously through social networking sites. Numerous consumers often play a more crucial role in social shopping context due to they not only purchase products and services but also share product information or their shopping experiences through WOM communication (Kim \& Park, 2013). Hence, such consumers can be utilized by the website manager of social shopping for maximizing WOM advertising which is less costly than traditional advertising (Kim \& Park, 2013). In addition, because some unique characteristics of social shopping, such characteristics can promote the formation of trust. As found by Linda (2010), information quality, communication, and WOM effects can make social shopping trustworthy as they are generated by consumers themselves. Moreover, as indicated by Stratmann (2010), consumers can depend on these features of social shopping such as customer ratings and reviews, user recommendations and referrals, and discussion boards to make purchase decisions. In short, as stated by Kim and Park (2013), information quality, communication between users and sellers, and WOM communication play crucial roles in the development of trustworthy social shopping sites.

Besides, as discussed by Hsiao et al. (2010), the application of social shopping such as eBay began more than 600 micro-social networks called eBay Neighborhoods in 2007 to increase social shopping on its site (http://neighborhoods.ebay.com/). The content from eBay.com incorporating eBay blogs, guides, reviews, and product search is combined into each eBay neighborhood. In eBay Neighborhoods, shoppers can join discussions, meet other people who share the similar consumer obsessions and easily obtain the webpages of product auctions (Hsiao et al., 2010). Besides, Stylehive is 
another sort of social shopping site. It elucidates itself as social bookmarking for products and shoppers. Stylehive permits users to bookmark their desired products, enhance pictures, and share them with concurring shoppers, family, and friends. Users enable Stylehive to also create personal wish-lists, which can also be classified and shared with family and friends (Hsiao et al., 2010).

Despite the significance of e-commerce in the economy, compared to large firms, small- and medium-sized merchants have faced numerous barriers to the adoption of innovations and contact to potential customers due to limited resources. However, the recent development of social shopping intermediaries now enables these merchants to tap into a large pool of local consumers. Social shopping intermediaries such as Groupon and LivingSocial not only provide information reach and richness to customers and participating merchants, but also make use of social networking. However, because social shopping is such a recent development, there is still a scarcity of studies on the behavioral and managerial aspects of the practice. This causes it very challenging for merchants to make notified decisions regarding social shopping promotions.

\section{Website quality}

Website quality is an important concept in e-commerce because the customers' perception of website quality directly affects their intentions to use a site (Chang, Chen, Hsu, \& Kuo, 2012; McCoy, Everard, \& Loiacono, 2009), and drives their purchase intentions (Liang \& Chen, 2009). Aladwani and Palvia (2002, p. 469) have defined customer's perception of website quality as “users' evaluations of a website's features meeting users' needs and reflecting overall excellence of the website". Thus, when evaluating a company's website offerings, understanding which aspect the website user considers the most important has become a priority for companies wishing to employ a 
successful e-strategy (Hernández, Jiménez, \& Martín, 2009). That is, in order to attract and retain customers, online retailers need to have a clear knowledge of what website qualities online customers expect (Lin, 2007), especially on social shopping websites. As indicated by Wang and Zhang (2012), social shopping is a usage of commerce mediated by social media (e.g., Facebook and Twitter) related convergence between the offline and online environments. Online retailers endeavor to take the advantage of social technologies and services to increase their businesses as social media has become freely accessible. More consumers view it as a source of information about companies, brands, products and services, even they can further share products and services in both online and offline marketplaces (Zhou, Zhang, \& Zimmermann, 2013). A recent study by Pinto (2015) shows that customers attitude toward social media can be an effective method to enhance satisfaction. Thus, insight into consumer perception about website quality is very important for making successful quality management practices for their social commerce (Ellahi \& Bokhari, 2013).

Lin (2007) indicated that website quality is a multi-dimensional construct comprising information quality, system quality and service quality. This three-dimensional measure of website quality could evaluate the principal factors that affect users' expectations and perceptions of website quality (DeLone \& McLean, 2003; Liang \& Chen, 2009; Wen 2012). This measure is consistent with the findings of Hernández et al. (2009) based on reviewing website quality-related literature from 1992-2007, that the quality of the information, of the system, and of the service provided by the firm through its website are the key factors of commercial website design. According to Lin (2007, p. 366-368), this three-dimensional website quality model is defined as follows. Information quality and system quality are evaluated from a technically-oriented perspective, while service quality from a customer-oriented 
perspective. Specifically, information quality is a measure of value perceived by a customer of the output produced by a website. System quality is manifested in a website system's overall performance, and it can be measured by the customer's perceived degree of user friendliness when shopping at an online retailer. Service quality is defined as the overall customer evaluation and judgment of the quality of online service delivery. DeLone and McLean (2003) suggested that these three factors play a key role in the satisfaction of online customers, which helps improve their purchase intentions (Bai, Law, \& Wen, 2008).

\section{Relationship quality}

Relationship quality relies on the interaction between the firm and its customers (Sanchez-Franco, Villarejo Ramos, \& Martin Velicia, 2009). Relationship quality is defined as "the degree of appropriateness of a relationship to fulfill the needs of the customers associated with that relationship" (Hennig-Thurau \& Klee, 1997, p.751). Numerous researchers such as Chung and Shin (2010) and Dorsch, Swanson, and Kelley (1998) agreed that relationship quality is a higher-order construct consisting of some distinct but related elements or dimensions (e.g., opportunism, customer orientation, conflict, trust, satisfaction, commitment, and perceived quality). However, most previous studies emphasized mainly on satisfaction (e.g., Jani \& Han, 2011; Zeithaml, Berry, \& Parasuraman, 1996), trust (e.g., Jani \& Han, 2011; Morgan \& Hunt, 1994), and/or commitment (e.g., Jani \& Han, 2011; Pritchard, Havitz, \& Howard, 1999) as predictors of behavioral intentions. Additionally, in recent years, we have witnessed the rapid growth of social shopping in Taiwan, but this growth has generated several transaction-related issues such as no delivery and the delivery of incorrect items as indicated by Kim and Park (2013). Such events can significantly influence customer satisfaction and repurchase intentions (Bitner, Blooms, \& Tetreault, 1990), and may also 
further generate negative eWOM (Sanchez-Garcia \& Curras-Perez, 2011) and influence known and unknown people to shop from the website. Thus, customer satisfaction is an important factor in the success of social shopping mediated by social media requiring managers to make more effort to increase satisfaction. By doing so, online businesses can easily get the customer's trust and commitment. Besides, Bloemer, De Ruyter, and Wetzels (1998) found that different relationship quality components are significant in different industries. Hence, based on preceding statement, this study tries to use relationship quality of social shopping consisting of three different but related dimensions, which are customer satisfaction, trust, and commitment. The study also aims to test the mediating roles of customer's trust and commitment in this paper.

\section{Satisfaction}

Satisfaction plays a crucial role in competitive environments of e-commerce due to its impact on behavioral intentions. Numerous practical and theoretical models of customer retention (e.g., Kumar, Kumari, Garza-Reyes, \& Lim, 2013; Kwon, \& Kim, 2012; Qi, Qu, \& Zhou, 2014) have viewed satisfaction as a critical determinant in consumer decisions to continue/discontinue their relationship with a given product or service. According to the expectancy disconfirmation model (EDM), users appraise a service or a product by comparing their service experience or product use against their expectation (Kucukarslan \& Nadkarni, 2008). Oliver (1997) pointed out that 'satisfaction' is defined as pleasurable fulfillment. Namely, the consumer perceives that consumption fulfills some need, desire, goal or so forth, and that this achievement is pleasurable. Hence, satisfaction is the consumer's feeling that consumption offers outcomes against a standard of pleasure versus displeasure.

\section{Commitment}


Customer commitment signifies a customer's craving to continue a positive, valued relationship with the product/service provider (Morgan \& Hunt, 1994; Sanchez-Franco et al., 2009). Specifically, commitment is the customer's long-term orientation towards a business relationship (Moorman, Zaltman, \& Deshpande, 1992). Morgan and Hunt (1994) suggested that commitment only exists when relationship is considered important and committed partner wants to maintain relationship indefinitely and is willing to work at maintaining it. Commitment is a significant variable for recognizing the strength of a marketing relationship (Dwyer, Schurr, \& Oh, 1987). Commitment can manifest itself in different ways like making adjustments to standard products or services, or by investing in the relationship (Johanson, Hallen, \& Seyed-Mohamed, 1991). Commitment is also a method of responding to customers' needs and is a crucial dimension of being market oriented (Kholi \& Jaworski, 1990; Lee, Lee, \& Lee, 2012).

\section{Trust}

Trust is the psychological status that makes a person willing to be vulnerable to another person and assumes favorable results of other's behavior (Sanchez-Franco et al., 2009). Lee and Turban (2001) proposed that the social-psychology perspective seems to be most related for realizing customers' trust in Internet shopping as it emphasizes on transactions. Trust is deemed as one of the most crucial prerequisites for e-commerce success. Mahmood, Bagchi, and Ford's (2004) study using the cross-country data from 26 nations show that the factors of trust and economic conditions make a significant positive contribution to online shopping behavior. Online transactions and exchange relationships are not only symbolized by uncertainty, but also by anonymity, absence of control and potential opportunism, making risk, and trust in crucial elements of e-commerce (Grabner-Krauter \& Kaluscha, 2003). There is also a great growth in the number of online retailers, which can potentially give consumers with a large array of 
alternatives and new sources of information. Specifically, this potential improvement in consumer dominance would also lead to enhanced role of trust in online retailing (Mukherjee \& Nath, 2007). Hence, it is difficult to expect that consumers would transact with online retailing without putting their basic trust in a specific vendor (Pang, Yen, \& Tarn, 2007).

\section{Purchase intention}

Identifying customers' purchase intentions is crucial as customers' behaviors can usually be predicted by their intentions. Purchase intention has been recognized as one of the dimensions of behavioral intention (Zeithaml et al., 1996). To examine customers' behavioral patterns, purchase intention has been applied to predict the actual behavior (Ajzen \& Fishbein, 1980). Purchase intention is supposedly correlated to actual behavior (Ajzen \& Fishbein, 1980; De Canniere et al., 2010; Wu \& Jang, 2014) and this relationship has been empirically tested in past studies (e.g., Ajzen \& Driver, 1992; Buttle \& Bok, 1996; Chow \& Murphy, 2011). Purchase intention is often driven by the positive word of mouth from the other social shoppers. A study in this area by Amblee and Bui (2011) show that eWOM becomes a collective signal of reputation, and ultimately a significant demand driver. Additionally, during the early visit to a website, the primary challenge that the social shopping service providers face is to convert visitors into buyers. A purchase directly influences both the revenue and profitability of the firm. Consequently, the significance of purchase intention as an outcome variable of interest in this study is clear. Accordingly, customer purchase intention is included as a significant dependent variable in our model.

\section{Hypothesis development}

Before undertaking the transaction, when consumers look for a product or service, place 
an order, and make payment over the Internet, they will ponder the perceived value they will achieve in terms of costs and benefits (Shih, 2004). Some scholars (e.g., Ahn, Ryu, \& Han, 2004; Kim, Lee, \& Law, 2008; Liu \& Arnett, 2000) have indicated that consumers' perceptions are mainly stemmed from three central factors of determining website quality, namely information, system, and service quality. Information quality means accuracy, timeliness, currency and reliability of information (Shih, 2004). The quality of the information that the system generates and transmits has been viewed as a crucial factor in affecting the information system's success (Lee \& Kozar, 2006). Information quality has a strong impact on customer satisfaction with Internet shopping (Janda, Trocchia, \& Gwinner, 2002; Szymanski \& Hise, 2000). Wu and Wang (2006) described that information quality is associated with an increase in user satisfaction. Chen and Cheng (2009) and $\mathrm{Wu}$ and Hsu (2015) have confirmed that the perceived information quality is positively related to satisfaction. Therefore, this study proposed the following hypothesis in social shopping:

H1: Perceived information quality is positively related to customer satisfaction of social shopping.

Furthermore, as indicated by Shih (2004), system quality implies the processing characteristics of an information system. Some researchers such as (e.g. Chen \& Cheng, 2009; Wu \& Hsu, 2015) revealed that system quality has a positive effect on satisfaction. McKinney, Yoon, and Zahedi, (2002) stated that customers dissatisfied with a website due to the poor system quality are likely to leave the site. Therefore, this study proposed the following hypothesis:

H2: Perceived system quality is positively related to customer satisfaction of social shopping. 
Besides, because social shopping combines e-commerce with Web 2.0 to offer a platform of social media (Constantinides, Romero, \& Boria, 2008), how to measure the service quality of social shopping website is a critical issue (Wu, Shen, \& Chang, 2015). Service quality perceived by customers derives from comparisons of their expectations with their perceptions of the real service performance (Parasuraman, Zeithaml, \& Berry, 1985). Shih (2004) pointed out that when consumers initially access websites to look for products or services, the perception of service quality (e.g., delivery timing, ease of returning merchandise, ease of payment, and protection of privacy) may encourage or discourage them from making a purchase through the Internet. In addition, Ahn, Ryu, and Han (2007) also proposed that service quality plays a crucial role in e-shopping as it is able to provide all the services (e.g., finding, ordering, and delivering the products) in the purchasing process. Thus, excellent service quality is critically important for e-businesses because online consumers deal with invisible retailers (Marsico and Levialdi, 2004). Specifically, owing to the lack of face-to-face communication, the perceived service quality of a website has to be concerned in an e-shopping context (Ahn et al., 2004). DeLone and McLean (2003) showed that service quality is critical to the success of e-commerce. Previous studies (Chang, Lee, \& Lai, 2012; Chen \& Cheng, 2009; Wu \& Hsu, 2015) have confirmed that customers are more satisfied with commercial websites when they perceive higher service quality. Therefore, this study proposed the following hypothesis:

H3: Perceived service quality is positively related to customer satisfaction of social shopping.

Relationship quality plays a significant role when exploring the associations that exist between customers and businesses. For instance, trust (Morgan \& Hunt, 1994), commitment (Jani \& Han, 2011), and satisfaction (Zeithaml et al., 1996) all positively 
affect customer purchasing behavior (Reichheld, 1996). Anderson and Mittal (2000) indicated that satisfied customers build trust and commitment, develop more positive intentions, and then purchase more from the company. Morgan and Hunt (1994) defined trust as the confidence in the exchange of partner's reliability and integrity. Pritchard et al. (1999) conceptualized commitment as the continuing desire to keep a valuable relationship. Zeithaml et al. (1996) explained that satisfaction is the overall assessment derived from the total purchase and consumption experience with a good or a service. Many researchers have studied the impact of the three components of relationship quality on purchase intention. For example, Sanchez-Franco et al. (2009) examined the influences of satisfaction, trust, and commitment on loyalty towards Internet service providers. They found that satisfaction significantly affects commitment and trust. Trust significantly influences commitment. Commitment and trust significantly influence loyalty. Furthermore, Walsh, Hennig-Thurau, Sassenberg, \& Bornemann (2010) investigated the effects of the relationship quality dimensions of customer satisfaction, trust, and commitment on customer loyalty. Jani and Han (2011) examined that the impacts of customer satisfaction, trust, and commitment on behavioral intentions, and found that customer satisfaction has a direct effect on trust but indirect effect on commitment. Consequently, based on the discussions above, the following hypotheses are developed:

H4: Customer satisfaction is positively related to commitment.

H5: Customer satisfaction is positively related to trust.

H6: Customer satisfaction is positively related to purchase intention of social shopping.

H7: Trust is positively related to commitment.

H8: Commitment is positively related to purchase intention of social shopping.

H9: Trust is positively related to purchase intention of social shopping. 


\section{Methodology}

Questionnaire survey is an effective and frequently used research method, and a scale instrument can help their conceptualization and operationalization (Chae, Kim, Kim, \& Ryu, 2002). This study aims to develop a scale for exploring the factors influencing purchase intention of social shopping. The development of this scale was based on the review of relevant literatures. All the questions in the scale are closed-ended questions, and the principles of exhaustion and mutual exclusion were carefully followed.

Furthermore, to test our research model, an empirical study using a web-based questionnaire was administered to actual Web customers. This social shopping website selected for this study is Rakuten Ichiba Taiwan (http://www.rakuten.com.tw/) due to several reasons as listed below.

1. This social shopping website is comprehensive and functional, eliminating any website problems.

2. Rakuten Ichiba Taiwan (http://www.rakuten.com.tw/) is a relatively unknown shopping website that guaranteed us enough first-time customers for our sample.

3. Rakuten Ichiba Taiwan (http://www.rakuten.com.tw/) sells various items such as clothing, shoes, bags, watch, food and drink and so on. This social shopping website is unlike booksellers like Booksamillion.com, primarily sells books.

\section{Pretest}

This study included a pretest to confirm the validity and reliability of the respondents' survey, who had prior experience with Internet shopping $(\mathrm{N}=41)$. They were asked to report any difficulties they may have encountered in the survey (e.g., ambiguous questions or terms) and also to state their opinion of the survey overall. Feedback and information from the pretest were used to develop a final survey questionnaire. Finally, 
based on the pilot test results, quantitative research experts reviewed and modified the wording of items.

\section{Sample and data collection}

This study collected data via an Internet survey using a convenience sample. Furthermore, as recommended by Lynn (2008), before collecting the data, this study sent a short letter to inform the sampled respondents about the upcoming survey to effectively manage non-respondents. Next, the hyperlink of the survey questionnaire was posted on the Facebook website for one month to invite the members to participate in this survey. Namely, they were asked to base their evaluation on their experience towards this social shopping website. In addition, the interviewers are thoroughly trained in how to ask respondents question, and starts with a short introduction and instruction. In order to increase the number of responses, in addition to ensuring that the survey was concise and the questions asked were clear, non-offensive and easy to respond to for the subjects, the hyperlink and invitation messages were posted on popular discussion forums, sent by e-mail and also an advertisement was placed which offered prizes to respondents who answered all the questions. All of the responses were anonymous and only used for academic purposes. After eliminating the incomplete and duplicate responses, 393 sample responses were used in the data analysis. Within the sample, 62.4 percent of respondents were female, and most respondents were 18-30 years of age. Besides, consistent with the approach of Hsu, Chen, Chang, and Chao (2010), this study used the extrapolation technique equating late responses to non-respondents to test the non-response bias. Responses were separated into two groups, specifically, those responding within fourteen days, and those responding after

fourteen days, according to the return date of questionnaires. $\chi^{2}$ difference test was conducted on demographic variables, which included gender, marital status, age, 
education, and occupation. No statistically significant differences were identified at $p<$ 0.05 , leading us to conclude that respondents were not different to non-respondents.

\section{Measurement development}

As shown in Appendix A, the constructs in this study were measured using a 7-point Likert-type scale and multiple items. All measurement items validated in previous studies were borrowed and slightly modified to be adequate for the present study. For all the measurement items across categories, scores ranged from 1 (strongly disagree) to 7 (strongly agree). In particular, the perception of information, system, and service quality were measured using five, three, and four items individually; three categories were adapted from Shih's work (2004). Customer satisfaction was measured using three items adapted from Garbarino and Johnson (1999) and Kim et al. (2006). Trust and commitment were measured by three items each; both categories were adapted from Morgan and Hunt (1994). Lastly, the three items for purchase intention were adapted from Pavlou and Gefen (2004). These modified items were thoroughly reviewed by academics (i.e., faculty members familiar with the subject and graduate students) and industry professionals (i.e., website managers and owners). Based on this expert review, subtle refinement of the questionnaire was made (sentence structure for question clarity, reselection of words, editorial corrections, etc.). As a next step, this preliminary questionnaire was pilot-tested with 41 customers who had experience of Internet shopping. The results of the pilot-test were used to lead to the adaption of existing scales wherever appropriate.

\section{Analysis and results}

\section{Scale purification}

This study performed descriptive statistical analysis, item correlation analysis, 
exploratory factor analysis (EFA), measurement model evaluation, and structural model evaluation to establish the scale's reliability and validity analysis, as well as to test the proposed hypothesized relationships in the research model. Quantitative analysis of the questionnaire was conducted using SPSS18.0 and LISREL8.54 software. The data was analyzed to verify the structure of the measurement scale, show the path analysis, and test the model fit. As proposed by Huang, Lin, and Fan (2015), PLS-PA or systems of regression equations can be applied for conducting path analysis, but they do not appropriately include all the necessary algorithms such as fit algorithms. As explained by Westland (2014), AMOS-LISREL type tools enable to provide fit algorithms, and in contrast, the PLS-PA tools cannot. Westland (2014) further indicated that PLS-PA analyses are mainly exploratory analysis tools, thus they do not fulfil our purpose of scale construction. Consistent with the way of Huang et al. (2015), the Q-Q plots are displayed in Appendix B which shows the distributions of all observations that are visually Normal. In addition, this study also calculated the skew and kurtosis coefficients to further confirm that the survey data are appropriate for analyses requiring normally-distributed data. As recommended thresholds by Kline (2005; p. 49-52), the absolute value of skew coefficients were less than 3 (with the highest being 1.179) and the absolute value of kurtosis coefficients were less than 7 (with the highest being 1.646). Descriptive statistical analysis was applied to show the profile of the respondents. Item analysis is important for the establishment of scale reliability, and missing value analysis was used to confirm the integrity of the data, after which corrected item-total correlation analysis was performed. This analysis is built on the associations between individual items relative to the items' total variances. Items that are inconsistent with the average behavior of other items will be deleted. The value of the corrected item-total correlation should be greater than .70. Item analysis is 
conducted before EFA, which determines the possible factors of the construct. In this study, after completing item analysis, EFA was conducted to establish the factor structure of each construct and to reduce the set of observed variables to a smaller variable set. A factor loading of .50 was applied as the threshold to further eliminate items. Next, the measurement model evaluation was undertaken to show the factor structure extracted by EFA and to measure both convergent and discriminant construct validity. Additionally, a more accurate estimation of adequate sample sizes can be calculated by Westland's (2010) formulas, and Bentler's (1989) and Bollen's (1989) rules of AMOS-LISREL analysis. Under the default condition "anticipated effect size: 0.1 , desired statistical power level: 0.8 , probability level: 0.05 ", the minimum sample sizes for the LISREL analysis of social shopping are 387 and 463, confirming that our sample size of 393 is adequate. Lastly, the structural equation modeling (SEM) was conducted by using the LISREL 8.54 program to test the hypothesized relationships in the proposed research model.

\section{Item analysis}

The scale items (24 for measuring purchase intention for social shopping) were refined by analyzing the data collected from respondents who had prior experience with Internet shopping. The first step in purifying the instrument was to delete items based on Cronbach's $\alpha$ and the corrected item-total correlations (Cronbach 1951). Consistent with the way of Huang et al. (2015), the item-total correlation test is applied to examine whether any item within the construct is irrelevant. As pointed out by Churchill (1979), it facilitates to purify the measure by eliminating "garbage items" before determining the construct factors, avoiding the production of too many factors in the later factor analysis stage. All of the measurement items chosen had corrected item-total correlations equal to or greater than .70 (Saxe \& Weitz, 1982). The Cronbach's $\alpha$ values 
were then recalculated. Finally, this study results in a 24 -item scale for exploring the factors affecting purchase intention of social shopping.

\section{Identifying the factor structure of the proposed model}

EFA was performed to explore the factor structure of the 24 item instruments in more detail. The set of data was analyzed concerning purchase intention for social shopping (393 valid responses). The Kaiser-Meyer-Olkin (KMO) and Bartlett's sphericity test generated a KMO measure greater than 0.7 and a significant Bartlett's sphericity test result, showing that the inter-correlation matrix contained a sufficient degree of common variance, and thus that EFA should be conducted.

\section{Exploratory factor analysis (EFA)}

EFA, using principal component analysis with equamax rotation, was conducted to identify the dimensionality of the 24 item scales. We extracted factors with eigenvalues greater than or equal to 1 , and thus finally yielding seven factors (i.e. perceived system quality, perceived information quality, customer satisfaction, commitment, trust, and purchase intention) which were consistent with the number of constructs in the research model in the social shopping context. The factor analysis procedure yielded a 7-factor (factor loadings: .650-.865), 24-item instrument (as Appendix A shown). The seven factors, which explained $87.89 \%$ of the variance in the dataset, were efficiency, fulfillment, contact, and responsiveness.

\section{Measurement model evaluation}

This study used SPSS for data analysis such as reliability and validity analysis. Specifically, to measure the internal consistency of constructs, the Cronbach alpha was calculated to test its reliability. The reliability of each construct in this study reaches an 
acceptable Cronbach alpha of over .7 (.90 - .97) (Nunnally, 1967). Furthermore, this study applied three measures mentioned in Fornell and Larcker (1981) including the item reliability of each measure, the composite reliability of each construct and the average variance extracted for each construct to evaluate the convergent validity of measurements. The item reliability of each measure was assessed using the factor loading of the underlying construct (Shih 2004). As shown in Table 1, the results showed that the factor loadings of all measures of the underlying constructs exceeded .5 (.65 - .87), and thus conformed to the test of item reliability (Hair, Anderson, Tatham, \& Black, 1995). Furthermore, the results confirmed that the composite reliabilities of all constructs exceeded the .7 cut-off value $(.78-.86)$ as recommended by Fornell and Larcker (1981). Additionally, it was found that the average variance extracted from each construct exceeded $.5(.53-.67)$, and thus showed convergent validity (Fornell \& Larcker, 1981). Overall, the convergent validity test indicated that the proposed constructs of the extended model were adequate.

[Insert Table 1 here]

Besides, discriminant validity was utilized to assess the extent to which the constructs differed. If the items in a construct were more strongly correlated with each other than with the items measuring other constructs, the measure was viewed as having discriminant validity. Table 2 shows the squared inter-correlations among the variables studied in this study. They represent the shared variance among the variables, and do not exceed the square root of average variance explained. As a result, discriminant validity is justified in this study.

[Insert Table 2 here] 


\section{Structural model evaluation}

To test the hypothesized relationships in the proposed research model, structural equation modeling (SEM) was conducted using the LISREL 8.54 program. Moreover, the maximum likelihood method was applied to analyze the collected data. The chi-square value $\left(\chi^{2}\right)$ of $739.32(\mathrm{df}=240, p<.001)$ was obtained, which indicates the goodness-of-fit. Furthermore, the $\chi^{2} / \mathrm{df}$ ratio was 3.081 , which increases the acceptability of the model as it is within the acceptable range of 2 to 5 (Marsh \& Hocevar, 1988). The other fit parameters of comparative fit index $(\mathrm{CFI}=.99)$ and normed fit index $(\mathrm{NFI}=.98)$ as well as the root mean square of approximation (RMSEA $=.073$ ) enhance the reliability of the model as they are below their acceptable levels (Byrne, 2010). The estimated coefficients are shown in Fig. 2, where statistically significant path coefficients are signified by solid lines. Of the nine hypotheses, $\mathrm{H} 1$ and H8 were not supported.

\section{[Insert Figure 2 here]}

From the structural model results shown in Fig. 2, it was found that only satisfaction and trust are positively related to purchase intention of social shopping.

Besides, in order to further test the mediating effect that commitment has on the link between satisfaction and purchase intention, this study used the method suggested by Baron and Kenny (1986), in which a variable functions as a mediator when it meets the following three conditions: 1) the independent variable significantly affects the dependent variable, 2) the independent variable significantly affects the mediating variable, and 3) when independent variable and mediating variable are considered together, the relationship between independent variable and dependent variable is not significant; the result means fully mediated. Otherwise, if the relationship between 
independent variable and dependent variable is significant and the coefficient is less than the coefficient of condition 1; the result means partially mediated. In the first condition, we found a significant positive impact of customer satisfaction on purchase intention $(\beta=.741, p<.001)$. Furthermore, in condition 2 , we found a significant positive impact of customer satisfaction on commitment $(\beta=.698, p<.001)$. Lastly, in condition 3 , we found that customer satisfaction $(\beta=.370, p<.001)$ and commitment $(\beta=.532, p<.001)$ significantly affect purchase intention, and the $\beta$ value is less than the $\beta$ value of condition 1 . Thus, our results showed that commitment partially mediated the relationship between satisfaction and purchase intention.

Again, we used the method of Baron and Kenny (1986) to test the mediating effect that trust has on the link between satisfaction and purchase intention. First, in condition 1, we found a significant positive impact of customer satisfaction on purchase intention $(\beta=.741, p<.001)$. Furthermore, in condition 2 , we found a significant positive impact of customer satisfaction on trust $(\beta=.696, p<.001)$. Lastly, in condition 3 , we found that customer satisfaction $(\beta=.465, p<.001)$ and trust $(\beta=.397, p<.001)$ significantly affect purchase intention, and the $\beta$ value is less than the $\beta$ value of condition 1 . Thus, our results also showed that trust partially mediated the relationship between satisfaction and purchase intention.

\section{Discussions and implications}

\section{Summary of the study}

This study adds to the current limited body of literature on social shopping and expands our knowledge on improving the purchase intention of consumers. In this study, the factors that affect consumers' purchase intention in social shopping were empirically 
investigated by using the proposed research model including website quality and relationship quality. Through SEM analysis, the significances noted in the paths and fit indices prove the model itself applicable to social shopping context.

\section{Implications for academic researchers}

Website quality and relationship quality have different impacts on purchase intention after social networking sites have obtained the global concerns. For example, while Facebook, Twitter, Cyworld, Plurk and so on have become well-known social networks platforms. Numerous commercial websites have allowed their members to use the account of social networking site to login in their websites. Specially, consumers are able to share any product information or to give the product comments to their friends on the social networking sites. On the other hand, consumers are able to get product information or the product comments from the friends of social networking sites. Thus, after browsing the social shopping websites, consumers' perceptions are possible to influence their purchase intention.

The rising competitiveness in e-commerce has prompted an exponential growth in the number of studies that analyze site characteristics and consequences. Hsu et al. (2012) found that perceived quality of e-shopping is critical to support online users, but it is necessary to offer further theoretical conceptualizations as well as detailed empirical evidence for such phenomena in which social shopping are supported and enabled. However, based on the empirical results of this study, we find that perceived information quality has no significant impact on customer satisfaction, which in turn, affects purchase intention of social shopping. This contradicts with some previous studies (e.g., Chen \& Cheng, 2009; Wu \& Hsu, 2015; Wu \& Wang, 2006) that empirically demonstrated that the information quality of a shopping website is a determinant of consumer satisfaction. Compared to the traditional e-commerce website, 
the particular characteristics (e.g., interaction with members of online community) of social shopping website, allow the information easier to achieve the goals of reliability, completeness, understandability, timeliness, and availability (Liang, Ho, Li, \& Turban, 2011-2012). More precisely, in social shopping, customers may acquire the information related to products and companies providing them not only from the website, but also from customers' families and friends. Therefore, perceived information quality does not significantly influence the customer satisfaction in the social shopping context.

In summary, on the theoretical level, this study provides empirical evidence showing that website quality plays a crucial role in social shopping environment. The current study highlights the importance of website quality (i.e. information, system and service quality) in understanding the intention to purchase from a social shopping site.

Additionally, this study fills the gap where there is a lack of studies examining the role of relationship quality in social shopping context. In the prior studies customer satisfaction is generally accepted as a strong predictor for behavioral variables such as trust, repurchase intentions, or loyalty (Ulaga \& Eggert, 2006). For now, there are a few of studies on customer satisfaction as the antecedent of trust and commit (Kim, 2002; Yoo \& Park, 2005; Choi, Choi, \& Lee, 2007). Although there are limited studies that analyze the relationship of satisfaction and trust or trust and commitment, few of studies focus on the hierarchical relationship among customer satisfaction, trust, and commitment. In addition, there are also limited studies on the relationship of trust, commitment, and purchase intention. It is clear from the earlier discussions that information offered by social shopping website may come from other known or unknown shoppers that may influence customers' perceived trust. Thus perceived trust is also needed to offer further detailed empirical evidence for such phenomena in which social shopping are supported and enabled. Based on the empirical results in this study, 
commitment has no significant impact on purchase intention of social shopping. This contradicts with Jani and Han (2011) who stated that commitment is a determinant of behavioral intentions. In social shopping, customers may be easier to attain opinions from others, particularly their families and friends. Generally, customers are satisfied with social shopping website and trust in it, and then directly affect their purchase intention towards it (Liang et al., 2011-2012). The purchase intentions may not be significantly dependable on the deep positive and valuable relationship with the service provider of shopping website. Furthermore, we find that perceived trust significantly influences commitment and purchase intention of social shopping. The finding implies that perceived trust is an important factor in social shopping context. In addition, purchase intention is becoming increasingly recognized as an important predictor of actual purchase, particularly within the online shopping, where trust plays a critical role in consumers' choices. Thus, it can be somewhat meaningful to identify the relationships among website quality, relationship quality, and purchase intention in social shopping context.

In summary, this study contributes to the predominantly theoretical literature on purchase intention from social shopping sites in general, and website quality and relationship quality. The finding of this study clearly extends prior research, and shows that relationship quality plays a key role in the social shopping environment. The concept of relationship quality is simple, but its mediating effect on purchase intention is not clear from past studies regarding how it affects the users' intention to purchase in a social shopping site. Hence, this study identifies the relationships between website quality, relationship quality and purchase intention by providing evidence to show that relationship quality plays a mediating role. Namely, the current study contributes to this field by offering a deeper understanding of the mediating effect of relationship quality 
on the intention to purchase in a social shopping site.

\section{Implications for practitioners}

There is an increasing importance on understanding the consumers' intention to purchase in a social shopping site. This study endeavors to help website managers in their efforts on improving the intention to purchase in a social shopping site. When building a relationship with consumers, it is crucial to improve the perceptions concerning social shopping websites. An excellent relationship quality can be built to enhance consumers' intention to purchase in a social shopping site. Website quality is expected to serve as an important antecedent of relationship quality, and in turn, affects purchase intention in social shopping. Thus, it is possible for social shopping websites to increase their sales when the improvement of website quality and relationship quality is achieved.

In short, our findings have important implications at managerial level. Firstly, when developing social shopping, online businesses should design the social shopping websites that better fit their needs and support social interaction among consumers to improve website quality (Huang \& Benyoucef, 2015). Specifically, online businesses should ensure the system reliability and offer the understandable, available, and timely information to help consumers make decisions before and during the purchase of a product or service. Furthermore, providing excellent service quality is also vital to increase customers' satisfaction, and on the other hand, as long as they are willing to share the good experience with familiar and unfamiliar people via social media, the effect of positive eWOM will occur and possibly further facilitate other people to shop from the social shopping website. Finally, to improve the customer's trust, commitment and intention to shop from the social shopping website, our findings have confirmed that customer satisfaction is a crucial factor and its important antecedent is the website 
quality. In other words, given the excellent website quality, it will be helpful to develop good relationship quality between online businesses and shoppers, resulting in further increases in their purchase intention in social shopping context.

\section{Limitations and further research directions}

Although our study has some important implications for academic researchers and practitioners, some limitations of the current research should be also noticed. Firstly, this study focused on investigating consumers' purchase intention rather than their actual purchasing behavior. Thus, it would be interesting to include real purchasing behavior in future research (Verhoef \& Langerak, 2001). Secondly, this study focused on examining the impacts of the perceived qualities towards social shopping website itself and the overall relationship with shoppers on purchase intention. Specifically, this study stated that shoppers' purchase intention may be influenced by known, unknown or website manager or both of them or all of them on this social shopping website. Hence, future research could focus on clarifying a role of an opinion leader and his/her impacts on shoppers' purchase intention of social shopping. Thirdly, the focus of this study was on the impact of relationship quality. However, we acknowledge that there are other factors that might also affect consumers' motivation to purchase socially-recommended products from websites. These factors may contain perceived risk (Jarvenpaa, Tractinsky, \& Vitale, 2000), subjective norms (Fishbein \& Ajzen, 1975), and perceived benefit (Swaminathan, Lepkowska-White, \& Rao, 1999). Hence, future research may explore the impacts of these factors on consumers' willingness to purchase from the social shopping. Additionally, the types of product may affect consumers' online purchase intentions (Hsiao et al., 2010), so this affect also can be tested in the social shopping context. Fourthly, we know that the service failure is inevitable in a web-based service industry, and consumers are easy to publicly express their opinions, experiences 
and complaints after a service failure. Specifically, consumers are inclined to disseminate negative WOM when they perceive an unfair response to a service failure (Seiders \& Berry, 1998). Thus, future research could include the construct of service recovery to explore its impact on purchase intentions as it has been identified by researchers and managers as an important element of customer service strategy. Finally, this study used a single social shopping website to serve as the subject. Thus, future research should examine whether the findings of this study can be generalizable to other social shopping websites. Moreover, this research could be rolled out to customers based in different countries and a cross country examination of these relationships could further help us generalize our findings across different countries.

\section{Acknowledgment}

This work was partially supported by the Ministry of Science and Technology, Taiwan, R.O.C. under grant MOST 102-2410-H-034-047-. 


\section{References}

Águila-Obra, A.R.D., \& Padilla-Meléndeza, A. (2013). The influence of electronic service quality on loyalty in postal services: the mediating role of satisfaction. Total Quality Management \& Business Excellence, 24(9), 1111-1123.

Ahn, T., Ryu, S., \& Han, I. (2004). The impact of online and offline features on the user acceptance of Internet shopping malls. Electronic Commerce Research and Applications, 3(4), 405-420.

Ahn, T., Ryu, S., \& Han, I. (2007). The impact of Web quality and playfulness on user acceptance of online retailing. Information \& Management, 44 (3), 263-275.

Ajzen, I., \& Driver, B.E. (1992). Applied of the theory of planned behavior to leisure choice. Journal of Leisure Research, 24(3), 207-224.

Ajzen, I., \& Fishbein, M. (1980). Understanding Attitudes and Predicting Social Behavior. Prentice-Hall, Englewood Cliffs, NJ.

Aladwani, A.M., \& Palvia, P.C. (2002). Developing and validating an instrument for measuring user-perceived web quality. Information \& Management, 39(6),

Amblee, N., \& Bui, T. (2011). Harnessing the influence of social proof in online shopping: The effect of electronic word of mouth on sales of digital microproducts. International Journal of Electronic Commerce, 16(2), 91-114.

Anderson, E.W., \& Mittal, V. (2000). Strengthening the satisfaction-profit chain. Journal of Service Research, 3(2), 107-120.

Bai, B., Law, R., \& Wen, I. (2008). The impact of website quality on customer satisfaction and purchase intentions: Evidence from Chinese online visitors. International Journal of Hospitality Management, 27(3), 391-402.

Bentler, P.M. (1989). EQS, Structural Equations, Program Manual, Program Version 3.0. BMDP Statistical Software Inc. Los Angeles, p. 6. 
Bilgihan, A., \& Bujisic, M. (2014). The effect of website features in online relationship marketing: A case of online hotel booking. Electronic Commerce Research and Applications, 14(4), 222-232.

Bitner, M.J., Blooms, B.H., \& Tetreault, M.S. (1990). The service encounter: Diagnosing favorable and unfavorable incidents. Journal of Marketing, 54(1), $71-84$

Bloemer, J., De Ruyter, K., \& Wetzels, M. (1998). Linking perceived quality and service loyalty: A multi-dimensional perspective. European Journal of Marketing, 33(11), 1082-1106.

Bollen, K.A. (1989). Structural Equations with Latent Variables. Wiley, New York, p. 268.

Buttle, F., \& Bok, B. (1996). Hotel marketing strategy and the theory of reasoned action. International Journal of Contemporary Hospitality Management, 8(3), 5-10.

Byrne, B.M. (2010). Structural Equation Modeling with AMOS: Basic Concepts, Applications, and Programming (2nd Edn.), Taylor and Francis Group, LLC, New York, USA.

Chae, M., Kim, J., Kim, H., \& Ryu, H. (2002). Information quality for mobile internet services: A theoretical model with empirical validation. Electronic Markets, 12(1), $38-46$.

Chang, H.H., Lee, C.H., \& Lai, C.Y. (2012). E-Service quality and relationship quality on dealer satisfaction: Channel power as a moderator. Total Quality Management \& Business Excellence, 23(7-8), 855-873.

Chang, K.C., Chen, M.C., Hsu, C.L., \& Kuo, N. T. (2012). Integrating loss aversion into a technology acceptance model to assess the relationship between website quality and website user's behavioural intentions. Total Quality Management \& Business 
Excellence, 23(7-8), 913-930.

Chen, C.W.D., \& Cheng. C.Y.J. (2009). Understanding consumer intention in online shopping: A respecification and validation of the DeLone and McLean model. Behaviour \& Information Technology, 28(4), 335-345.

Chen, Y.H., \& Barnes, S. (2007). Initial trust and online buyer behaviour. Industrial Management \& Data Systems, 107(1), 21-36.

Choi, Y.G., Choi, D.C., \& Lee, S.S. (2007). The effect of components of interactivity on satisfaction, trust, commitment and loyalty in online community. Journal of Quality Management, 35(4), 123-139.

Chow, I., \& Murphy, P. (2011). Predicting intended and actual travel behaviors: An examination of Chinese outbound tourists to Australia. Journal of Travel \& Tourism Marketing, 28(3), 318-330.

Chung, K.H., \& Shin, J.I. (2010). The antecedents and consequents of relationship quality in internet shopping. Asia Pacific Journal of Marketing and Logistics, $22(4), 473-491$.

Churchill, G.A. (1979). A paradigm for developing better measures of marketing constructs. Journal of Marketing Research, 16(1), 64-73.

Constantinides, E., Romero, L.R., \& Boria, M.A.G. (2008). Social media: A new frontier for retailers? European Retail Research, 22, 1-28.

Cronbach, L.J. (1951). Coefficient alpha and the internal structure of tests. Psychometrika, 16(13), 297-334.

De Canniere, M.H., De Pelsmacker, P., \& Geuens, M. (2010). Relationship quality and purchase intention and behavior: The moderating impact of relationship strength. Journal of Business and Psychology, 25(1), 87-98.

De Wulf, K., Odekerken-Schroder, G., \& Lacobucci, D. (2001). Investments in 
consumer relationships: A cross-country and cross-industry exploration. Journal of Marketing, 65(4), 33-50.

DeLone, W., \& McLean, E. (2003). The DeLone and McLean model of information systems success: A ten year update. Journal of Management Information Systems, 19(4), 9-30.

Dorsch, M.J., Swanson, S.R., \& Kelley, S.W. (1998). The role of relationship quality in the stratification of vendors as perceived by customers. Journal of the Academy of Marketing Science, 26(2), 128-142.

Dwyer, F. R., Schurr, P. H., \& Oh, S. (1987). Developing buyer-seller relationships. Journal of Marketing, 51(2), 11-27.

EMarketer. (2008). The growing influence of online social shoppers, Available at: www. emarketer.com/Article.aspx?id¹/41006146 (accessed 1 July 2009).

Fishbein, M., \& Ajzen, I. (1975). Belief, Attitude, Intention Behavior: An Introduction to Theory and Research. Addison-Wesley, Reading, MA.

Fornell, C., \& Larcker, D.F. (1981). Evaluating structural equation models with unobservable variables and measurement error. Journal of Marketing Research, $18(1), 39-50$.

Garbarino, E., \& Johnson, M.S. (1999). The different roles of satisfaction, trust and commitment in customer relationships. Journal of Marketing, 63(2), 70-87.

Gordon, K.T. (2007). Looking for ways to get people talking about your products? The new social shopping trend can help you build buzz. Available at: www.entrepreneur.com/marketing/onlinemarketing/article174746.html (accessed 1 July 2009).

Grabner-Krauter, S., \& Kaluscha, E. (2003). Empirical research in online trust: A review and critical assessment. International Journal of Human-Computer Studies, 58(6), 
783-812.

Hair, J.F., Anderson, R.E., Tatham, R.L., \& Black, W.C. (1995). Multivariate Data Analysis with Readings. Prentice-Hall, Englewood Cliffs, NJ.

Hajli, M.N. (2014). The role of social support on relationship quality and social commerce. Technological Forecasting \& Social Change, 87, 17-27.

Hajli, N. (2015). Social commerce constructs and consumer's intention to buy. International Journal of Information Management, 35(2), 183-191.

Hennig-Thurau, T., \& Klee, A. (1997). The Impact of customer satisfaction and relationship quality on customer retention-a critical reassessment and model development. Psychology \& Marketing, 14(8), 737-765.

Hernández, B., Jiménez, J., \& Martín, M.J. (2009). Key website factors in e-business strategy. International Journal of Information Management, 29(5), 362-371.

Hsiao, K.L., Lin, J.C.C., Wang, X.Y., Lu, H.P., \& Yu, H. (2010). Antecedents and consequences of trust in online product recommendations: an empirical study in social shopping. Online Information Review, 34(6), 935-953.

Hsu, C.L., Chen, M.C., Chang, K.C., \& Chao, C.M. (2010). Applying loss aversion to investigate service quality in logistics: A moderating effect of service convenience. International Journal of Operations \& Production Management, 30(5), 508-525.

Hsu, C.L., Wu, C.C., Chen, M.C., \& Chang, K.C. (2012). Formation of e-satisfaction and e-loyalty: An extension of technology acceptance model with perceived quality and flow experience. Journal of Quality, 19, 161-83.

Huang, E.Y., Lin, S.W., \& Fan, Y.C. (2015). M-S-QUAL: Mobile service quality measurement. Electronic Commerce Research and Applications, 14(2), 126-142.

Huang, Z., \& Benyoucef, M. (2015). User preferences of social features on social commerce websites: An empirical study. Technological Forecasting and Social 
Change, 95, 57-72.

Janda, S., Trocchia, P.J., \& Gwinner, K.P. (2002). Consumer perceptions of Internet retail service quality. International Journal of Service Industry Management, 13(5), 412-431.

Jani, D., \& Han, H. (2011). Investigating the key factors affecting behavioral intentions: Evidence from a full-service restaurant setting. International Journal of Contemporary Hospitality Management, 23(7), 1000-1018.

Jarvenpaa, S.L. Tractinsky, N., \& Vitale, M. (2000). Consumer trust in an Internet store. Information Technology and Management, 1(1-2), 45-71.

Johanson, J., Hallen, L., \& Seyed-Mohamed, N. (1991). Interfirm adaptation in business relationships. Journal of Marketing, 55(2), 29-37.

Kholi, A.K., \& Jaworski, B.J. (1990). Market orientation: The construct, research propositions, and managerial implications. Journal of Marketing, 54(2), 1-18.

Kim, S.W. (2002). The relationship of internet shopping mall characteristics, relationship quality and customer loyalty. Journal of Business Research, 17(4), $247-273$

Kim, W., Lee, Y., \& Yoo, Y. (2006). Predictors of relationship quality and relationship outcomes in luxury restaurants. Journal of Hospitality \& Tourism Research, 30(2), 143-169.

Kim, T.G., Lee, J.H., \& Law, R. (2008). An empirical examination of the acceptance behaviour of hotel front office systems: An extended technology acceptance model. Tourism Management, 29(3), 500-513.

Kim, S., \& Park, H. (2013). Effects of various characteristics of social commerce (s-commerce) on consumers' trust and trust performance. International Journal of Information Management, 33(2), 318-332. 
Kline, R.B. (2005). Principles and Practice of Structural Equation Modeling, 2nd edition. The Guilford Press, New York.

Kucukarslan, S.N., Nadkarni, A. (2008). Evaluating medication-related services in a hospital setting using the disconfirmation of expectations model of satisfaction. Research in Social \& Administrative Pharmacy, 4(1), 12-22.

Kumar, V., Kumari, A., Garza-Reyes, J.A., \& Lim, M. (2013). Dependability a Key Element for Achieving Competitive Advantage: A Study of Information Service Firms. In Advances in Production Management Systems. Sustainable Production and Service Supply Chains, 493-500, Springer, Berlin Heidelberg.

Kwon, K., \& Kim, C. (2012). How to design personalization in a context of customer retention: who personalizes what and to what extent? Electronic Commerce Research and Applications, 11(2), 101-116.

Lee, I., \& Lee, K. (2012). Social shopping promotions from a social merchant's perspective. Business Horizons, 55(5), 441-451.

Lee, J., Lee, Y., \& Lee, Y.J. (2012). Do customization programs of e-commerce companies lead to better relationship with consumers? Electronic Commerce Research and Applications, 11(3), 262-274.

Lee, M.K.O., \& Turban, E. (2001). A trust model for consumer Internet shopping. International Journal of Electronic Commerce, 6(1), 75-91.

Lee, Y., \& Kozar, K.A. (2006). Investigating the effect of website quality on e-business success: An analytic hierarchy process (AHP) approach. Decision Support Systems, 42(3), 1383-1401.

Liang, C.J., \& Chen, H.J. (2009). A study of the impacts of website quality on customer relationship performance. Total Quality Management \& Business Excellence, 20(9), 971-988. 
Liang, T.P., Ho, Y.T., Li, Y.W., \& Turban, E. (2011-2012). What drives social commerce: the role of social support and relationship quality. International Journal of Electronic Commerce, 16(2), 69-90

Lin, H.F. (2007). The impact of website quality dimensions on customer satisfaction in the B2C e-commerce context. Total Quality Management \& Business Excellence, 18(4), 363-378.

Linda, S.L.A.I. (2010). Social commerce - e-commerce in social media context. World Academy of Science. Engineering and Technology, 72, 39-44.

Liu, C., \& Arnett, K.P. (2000). Exploring the factors associated with Web site success in the context of electronic commerce. Information \& Management, 38(1), 23-33.

Lynn, P. (2008). The Problem of Non-Response, In de Leeuw, E.D., Hox, J.J., Dillman, D.A., (Eds.). International handbook of survey methodology. New York: Psychology Press, 35-55.

Mahmood, M.A., Bagchi, K., \& Ford, T.C. (2004). On-line shopping behavior: Cross-country empirical research. International Journal of Electronic Commerce, 9(1), 9-30.

Marsh, H.W., \& Hocevar, D. (1988). A new, more powerful approach to multitrait-multimethod analyses, application of second-order confirmatory factor analysis. Journal of Applied Psychology, 73(1), 107-117.

Marsico, M.D., \& Levialdi, S. (2004). Evaluating web sites: Exploiting user's expectations. International Journal of Human-Computer Studies, 60 (3), 381-416.

McCoy, S., Everard, A., \& Loiacono, E.T. (2009). Online ads in familiar and unfamiliar sites: Effects on perceived website quality and intention to reuse. Information Systems Journal, 19(4), 437-458.

McKinney, V., Yoon, K., \& Zahedi, F.M. (2002). The measurement of web-customer 
satisfaction: An expectation and disconfirmation approach. Information Systems Research, 13(3), 296-315.

Moorman, C., Zaltman, G., \& Deshpande, R. (1992). Relationships between providers and users of marketing research: The dynamics of trust within and between organizations. Journal of Marketing Research, 29(3), 314-329.

Morgan, R.M., \& Hunt, S.D. (1994). The commitment-trust theory of relationship marketing. Journal of Marketing, 58(3), 20-38.

Mukherjee, A., \& Nath, P. (2007). Role of electronic trust in online retailing: A re-examination of the commitment-trust theory. European Journal of Marketing, 41(9/10), 1173-1202.

Nunnally, J. (1967). Psychometric Theory. New York, NY: McGraw-Hill.

Olbrich, R., \& Holsing, C. (2011). Modeling consumer purchasing behavior in social shopping communities with clickstream data. International Journal of Electronic Commerce, 16(2), 15-40.

Oliver, R.L. (1997). Satisfaction: A Behavioral Perspective on the Consumer. New York, NY: McGraw-Hill.

Pang, C., Yen, D.C., \& Tarn, J.M. (2007). Exploring online shoppers' e-trust in China. Human Systems Management, 26(3), 193-198.

Parasuraman, A., Zeithaml, V.A., \& Berry, L.L. (1985). A conceptual model of service quality and its implications for future research. Journal of Marketing, 49(4), 41-50.

Pavlou, P.A., \& Gefen, D. (2004). Building effective online marketplaces with institution-based trust. Information Systems Research, 15(1), 37-59.

Pinto, M. B. (2015). Social media's contribution to customer satisfaction with services. The Service Industries Journal, 35(11-12), 573-590. 
Pritchard, M., Havitz, M., \& Howard, D. (1999). Analyzing the commitment-loyalty link in service contexts. Journal of the Academy of Marketing Science, 27(3), $333-348$.

Qi, J.Y., Qu, Q.X., \& Zhou, Y.P. (2014). How does customer self-construal moderate CRM value creation chain? Electronic Commerce Research and Applications, 13(5), 295-304.

Rafiq, M., Fulford, H., \& Lu, X. (2013). Building customer loyalty in online retailing: The role of relationship quality. Journal of Marketing Management, 29(3-4), 494-517.

Rauyruen, P., \& Miller, K. E. (2007). Relationship quality as a predictor of B2B customer loyalty. Journal of Business Research, 60(1), 21-31.

Reichheld, F.F. (1996). The Loyalty Effect: The Hidden Force behind Growth, Profits, and Lasting Value. Boston, USA: Harvard Business School Press.

Rubel, S. (2005). Trends to watch. Part II: Social commerce - micro persuasion. Available at: www.micropersuasion.com/2005/12/2006_trends_to_.html (accessed 1 July 2009).

Sanchez-Franco, M.J., Villarejo Ramos, A.F., \& Martin Velicia, F.A. (2009). The moderating effect of gender on relationship quality and loyalty toward Internet service providers. Information \& Management, 46(3), 196-202.

Sanchez-Garcia, I., \& Curras-Perez, R. (2011). Effects of dissatisfaction in tourist services: The role of anger and regret. Tourism Management, 32(6), 1397-1406.

Saxe, R., \& Weitz, B.A. (1982). The SOCO scale: A measure of the customer orientation of salespeople. Journal of Market Research, 19(3), 343-351.

See-To, E.W.K., \& Ho, K.K.W. (2014). Value co-creation and purchase intention in social network sites: The role of electronic Word-of-Mouth and trust - A 
theoretical analysis. Computers in Human Behavior, 31, 182-189.

Seiders, K., \& Berry, L.L. (1998). Service fairness: What it is and why it matters. The Academy of Management Executive, 12 (2), 8-20.

Shih, H. (2004). An empirical study on predicting user acceptance of e-shopping on the Web. Information \& Management, 41(3), 351-368.

Stratmann, J. (2010). Social commerce - the future of e-commerce. Fresh networks. http://www.freshnetworks.com/blog/2010/07/social-commerce-future-ecommerce

Swaminathan, V., Lepkowska-White, E., \& Rao, B.P. (1999). Browsers or buyers in cyberspace? An investigation of factors influencing electronic exchange. Journal of Computer Mediated Communication, 5(2).

Szymanski, D.M., \& Hise, R.T. (2000). E-Satisfaction: An initial examination. Journal of Retailing, 76(3), 309-322.

Ulaga, W., \& Eggert A. (2006). Relationship value and relationship quality: Broadening the nomological network of business-to-business relationships. European Journal of Marketing, 40(3/4), 311-327.

Verhoef, P.C., \& Langerak, F. (2001). Possible determinants of consumers' adoption of electronic grocery shopping in the Netherlands. Journal of Retailing and Consumer Services, 8(5), 275-285.

Walsh, G., Hennig-Thurau, T., Sassenberg, K., \& Bornemann, D. (2010). Does relationship quality matter in e-services? A comparison of online and offline retailing. Journal of Retailing and Consumer Services, 17(2), 130-142.

Wang, C., \& Zhang, P. (2012). The evolution of social commerce: An examination from the people, business, technology, and information perspective. Communication of the Association for Information Systems, 31(5), 105-127.

Wen, I. (2012). An empirical study of an online travel purchase intention model. Journal 
of Travel \& Tourism Marketing, 29(1), 18-39.

Westland, J.C. (2014). Statistical Power and Sample Size in PLS Path Analysis. August 29. Available at SSRN: http://ssrn.com/abstract=2488982.

Westland, J.C. (2010). Lower bounds on sample size in structural equation modeling. Electronic Commerce Research and Applications, 9(6), 476-487.

Wu, C.C., \& Hsu, C.L. (2015). How to improve e-satisfaction and e-loyalty and strengthen the links between them: Value from regulatory fit. Human Factors and Ergonomics in Manufacturing \& Service Industries, 25(3), 353-369.

Wu, J.H., \& Wang, Y.M. (2006). Measuring KMS success: A respecification of the DeLone and McLean's model. Information \& Management, 43(6), 728-739.

Wu, S.I., \& Jang, J.Y. (2014). The impact of ISO certification on consumers' purchase intention. Total Quality Management \& Business Excellence, 25(4), 412-426.

Wu, Y.C.J., Shen, J.P., \& Chang, C.L. (2015). Electronic service quality of Facebook social commerce and collaborative learning. Computers in Human Behavior, 51 (Part B), 1395-1402.

Yoo, S.J., \& Park, N.H. (2005). The Effect between cognitive characteristics, relationship quality and purchase intention on shopping mall web site. Journal of Small Business Studies, 27(1), 195-218.

Zeithaml, V.A., Berry, L.L., \& Parasuraman, A. (1996). The behavioral consequences of service quality. Journal of Marketing, 60(2), 31-46.

Zhou, L., Zhang, P., \& Zimmermann, H.D. (2013). Social commerce research: an integrated view. Electronic Commerce Research and Applications, 12(2), 61-68. 


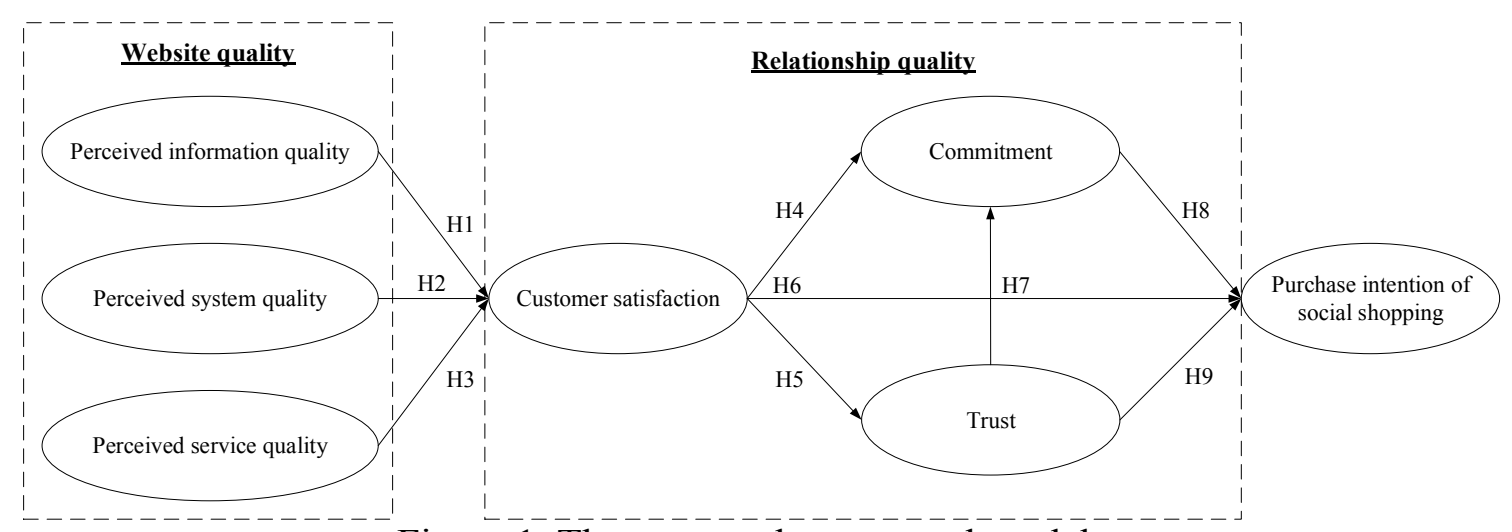

Figure 1. The proposed conceptual model.

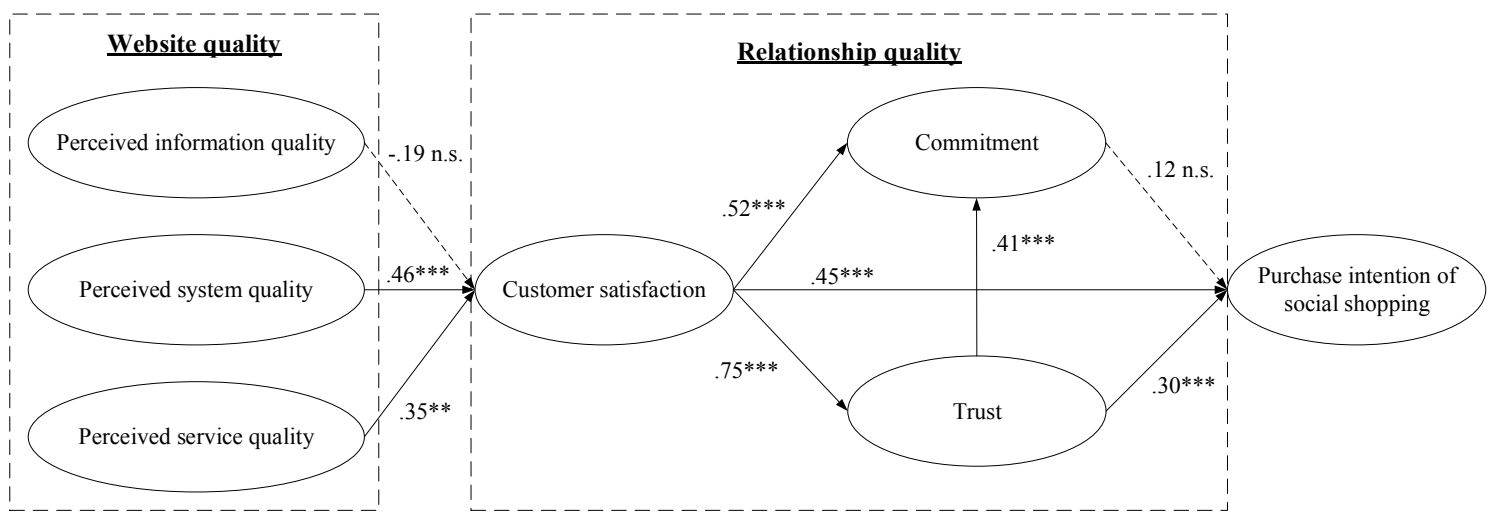

Figure 2. Structural model results $(*, p<.05 ; * *, p<.01 ; * * *, p<.001 ;$ n.s. means not significant). 
Table 1. Reliability and factor loadings.

\begin{tabular}{|c|c|c|c|c|}
\hline & Factor loading & $\begin{array}{l}\text { Composite } \\
\text { reliability }\end{array}$ & $\begin{array}{l}\text { Average variance } \\
\text { extracted (AVE) }\end{array}$ & Cronbach's $\alpha$ \\
\hline Perceived system quality & & .86 & .67 & .90 \\
\hline Perceived system quality 1 & .87 & & & \\
\hline Perceived system quality 2 & .85 & & & \\
\hline Perceived system quality 3 & .72 & & & \\
\hline Perceived information quality & & .85 & .53 & .96 \\
\hline Perceived information quality 1 & .72 & & & \\
\hline Perceived information quality 2 & .76 & & & \\
\hline Perceived information quality 3 & .76 & & & \\
\hline Perceived information quality 4 & .67 & & & \\
\hline Perceived information quality 5 & .71 & & & \\
\hline Perceived service quality & & .80 & .56 & .91 \\
\hline Perceived service quality 1 & .74 & & & \\
\hline Perceived service quality 2 & .84 & & & \\
\hline Perceived service quality 3 & .75 & & & \\
\hline Perceived service quality 4 & .65 & & & \\
\hline Customer satisfaction & & .85 & .65 & .95 \\
\hline Customer satisfaction 1 & .81 & & & \\
\hline Customer satisfaction 2 & .81 & & & \\
\hline Customer satisfaction 3 & .80 & & & \\
\hline Commitment & & .78 & .54 & .94 \\
\hline Commitment 1 & .70 & & & \\
\hline Commitment 2 & .77 & & & \\
\hline Commitment 3 & .74 & & & \\
\hline Trust & & .84 & .64 & .95 \\
\hline Trust 1 & .82 & & & \\
\hline Trust 2 & .78 & & & \\
\hline Trust 3 & .80 & & & \\
\hline
\end{tabular}


Purchase intention 1

Purchase intention 2

Table 2. Squared inter-correlation among the constructs.

\begin{tabular}{|c|c|c|c|c|c|c|c|c|}
\hline & & 1 & 2 & 3 & 4 & 5 & 6 & 7 \\
\hline 1 & Perceived system quality & .82 & & & & & & \\
\hline 2 & Perceived information quality & .48 & .73 & & & & & \\
\hline 3 & Perceived service quality & .30 & .67 & .75 & & & & \\
\hline 4 & Commitment & .26 & .27 & .25 & .81 & & & \\
\hline 5 & Trust & .17 & .15 & .14 & .57 & .73 & & \\
\hline 6 & Customer satisfaction & .19 & .16 & .17 & .49 & .48 & .80 & \\
\hline 7 & Purchase intention & .26 & .27 & .25 & .62 & .52 & .55 & .76 \\
\hline
\end{tabular}

Notes: All correlations are significant at the 0.05 level.

The diagonals represent the square root of average variance extracted (AVE). 


\section{Appendix A: Measures for constructs}

\section{Perceived system quality}

1. The query supporting function of social shopping website will influence my decision to shop on this social shopping website.

2. The functions of search engines will influence my decision to shop from social shopping website.

3. The reliability of social shopping website will influence my decision to shop on this social shopping website.

\section{Perceived information quality}

1. Accuracy of information will influence my decision to shop from social shopping website.

2. Completeness of information will influence my decision to shop from social shopping website.

3. Understandability of information will influence my decision to shop from social shopping website.

4. Timeliness of information will influence my decision to shop from social shopping website.

5. Availability of information will influence my decision to shop from social shopping website.

\section{Perceived service quality}

1. Delivery timing will influence my decision to shop from social shopping website.

2. Ease of returning merchandise will influence my decision to shop from social shopping website.

3. Ease of payment will influence my decision to shop from social shopping website.

4. Privacy protection will influence my decision to shop from social shopping website.

\section{Customer satisfaction}

1. How would you rate your level of satisfaction with this social shopping website?

2. How would you rate your overall satisfaction with this social shopping website? 
3. How would you rate this social shopping website compared with other shopping websites on overall satisfaction?

\section{Commitment}

1. I am very committed to this social shopping website.

2. I intend to maintain a relationship definitely.

3. I think this social shopping website deserves my effort to maintain a relationship.

\section{Trust}

1. I think this social shopping website is reliable.

2. I have confidence on this social shopping website.

3. I think this social shopping website has high integrity.

\section{Purchase intention}

1. Given the chance, I would consider purchasing products from this social shopping website in the future.

2. It is likely that I would actually purchase products from this social shopping website in the near future.

3. Given the chance, I intend to purchase products from the social shopping website. 


\section{Appendix B. Q-Q plots of observations}

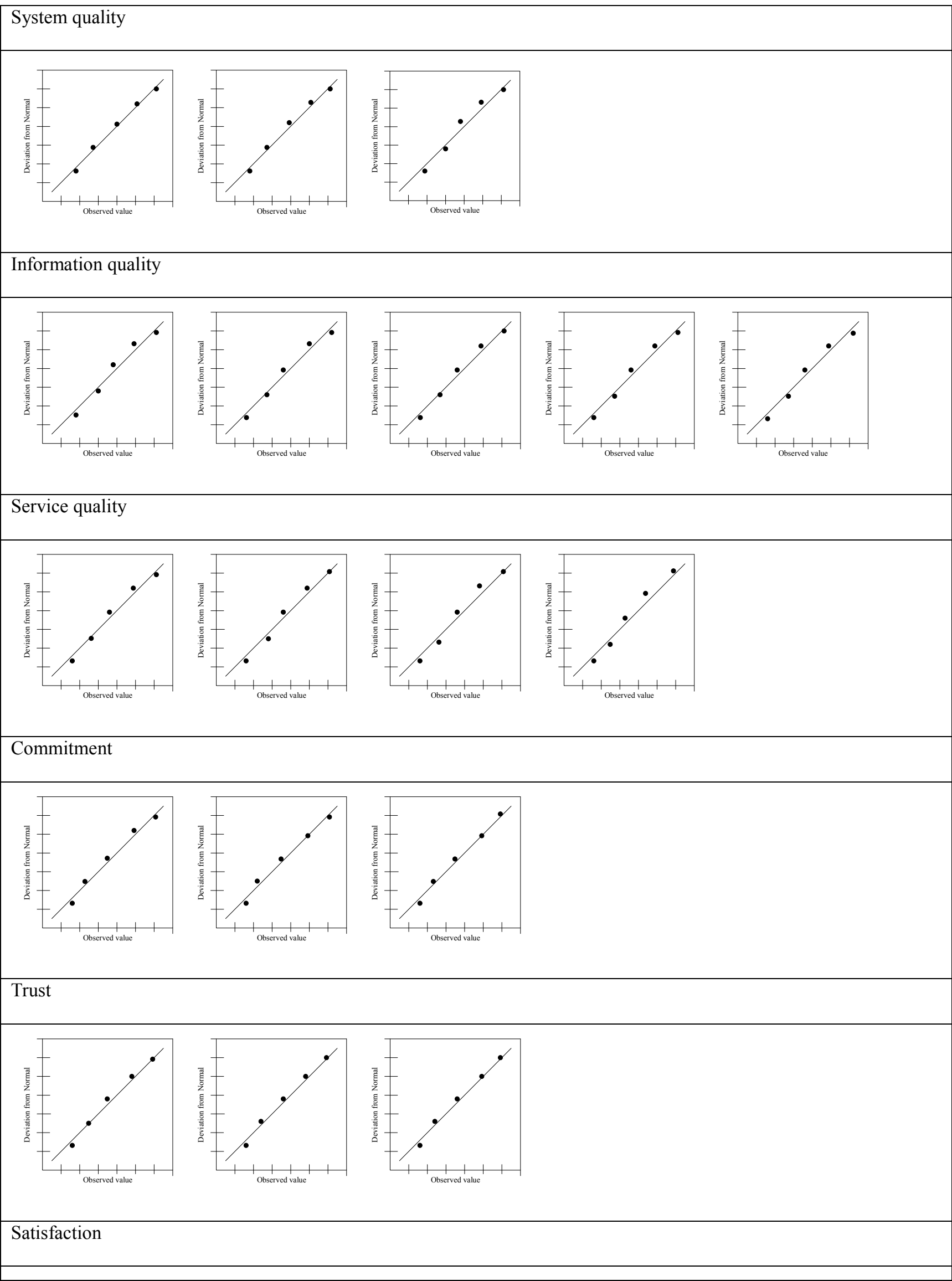




Purchase intention

